$\begin{array}{llccccccr}\text { Volume } & 12, \quad \text { Nomor } & 1, \quad \text { Mei } & \text { 2020, } & \text { pp } & 137-145 & \text { Copyright } & \text { C } & 2017 \\ \text { Jurnal } & \text { Akuntansi, } & \text { Program } & \text { Studi } & \text { Akuntansi, } & \text { Fakultas } & \text { Ekonomi, } \\ \text { Universitas } & \text { Kristen } & \text { Maranatha. } & \text { ISSN } & 2085-8698 & \text { e-ISSN } & 2598-4977 .\end{array}$

http://journal.maranatha.edu

\title{
Pengaruh Investasi Asing dan Investasi Dalam Negeri terhadap Pertumbuhan Ekonomi Indonesia
}

\author{
Herman Kambono \\ Fakultas Ekonomi Program Studi Akuntansi Universitas Kristen Maranatha \\ (Jl. Prof. drg. Suria Sumantri No. 65, Bandung) \\ herman.kambono@yahoo.com \\ Elyzabet Indrawati Marpaung \\ Fakultas Ekonomi Program Studi Akuntansi Universitas Kristen Maranatha \\ (J1. Prof. drg. Suria Sumantri No. 65, Bandung) \\ elyzabetm@yahoo.com
}

\begin{abstract}
One of the objectives of conducting investment both PMDN investment (Domestic Investment) and PMA (Foreign Investment) is to increase economic growth. This study aims to analyze the effect of Foreign Investment and Domestic Investment on economic growth. The data used is Indonesian macro economic time series data in 2011. Data were analyzed using multiple regression methods.The results showed that foreign investment had a significant positive effect on economic growth, while domestic investment had no effect on economic growth.The implication in this study is the need for the role of the government as a regulator to support increased foreign investment and domestic investment so as to enhance Indonesia's economic growth.
\end{abstract}

Keywords: Domestic Investment, Foreign Investment, and Economic Growth

\begin{abstract}
Abstrak
Salah satu tujuan melakukan investasi, baik investasi PMDN (Investasi Domestik) maupun PMA (Investasi Asing) adalah untuk meningkatkan pertumbuhan ekonomi. Penelitian ini bertujuan untuk menganalisis pengaruh investasi asing dan investasi domestik terhadap pertumbuhan ekonomi. Data yang digunakan adalah data time series makro ekonomi Indonesia pada tahun 2011. Data dianalisis menggunakan metode regresi berganda. Hasil penelitian menunjukkan bahwa investasi asing berpengaruh positif signifikan terhadap pertumbuhan ekonomi, sedangkan investasi domestik tidak berpengaruh terhadap pertumbuhan ekonomi. Implikasi dalam penelitian ini adalah perlunya peran pemerintah sebagai regulator untuk mendukung peningkatan investasi asing dan investasi domestik sehingga dapat meningkatkan pertumbuhan ekonomi Indonesia.
\end{abstract}

Kata Kunci: Investasi Dalam Negeri, Investasi Asing, dan Pertumbuhan Ekonomi 


\section{Pendahuluan}

Pertumbuhan ekonomi merupakan kejadian ekonomi yang bersifat jangka panjang dan merupakan standar hidup ekonomi masyarakat. Istilah pertumbuhan ekonomi digunakan untuk menggambarkan terjadinya kemajuan atau perkembangan ekonomi dalam suatu negara (Murni, 2016).

Dengan mengamati tingkat pertumbuhan yang tercapai dari tahun ke tahun dapatlah dinilai prestasi dan kesuksesan negara tersebut dalam mengendalikan kegiatan ekonominya dalam jangka pendek dan usaha mengembangkan perekonomiannya dalam jangka panjang. Perbandingan juga dapat dilakukan di antara tingkat kesuksesan negara itu dalam mengendalikan dan membangun perekonomiannya apabila dibandingkan dengan yang dicapai negara-negara lain (Sukirno, 2013).

Setiap pembangunan ekonomi diharapkan dapat merangsang pertumbuhan ekonomi dengan peningkatan pendapatan nasional atau pendapatan per kapita masyarakat. Dengan adanya pembangunan ekonomi, akan terjadi pertumbuhan ekonomi yaitu proses peningkatan produksi barang dan jasa dalam kegiatan ekonomi masyarakat. Adanya pertumbuhan ekonomi merupakan indikasi keberhasilan pembangunan ekonomi (Murni, 2016).

Harrod-Domar, dalam teorinya mengemukakan syarat-syarat yang harus dipenuhi supaya suatu perekonomian dapat mencapai pertumbuhan yang tangguh atau steady growth dalam jangka panjang yaitu perlunya investasi (Murni, 2016). Investasi tersebut dapat berupa Penanaman Modal Dalam Negeri (PMDN) maupun Penanaman Modal Luar Negeri (PMA).

UU Penanaman Modal No. 25 Tahun 2007 menyebutkan bahwa salah satu tujuan dari penyelenggaraan investasi baik investasi PMDN (Penanaman Modal Dalam Negeri) maupun PMA (Penanaman Modal
Asing) adalah meningkatkan pertumbuhan ekonomi nasional yang selanjutnya tidak hanya meningkatkan pertumbuhan ekonomi tetapi juga akan memeratakan dan meningkatkan kesejahteraan nasional secara kontinu yang disebut sebagai pembangunan ekonomi.

Penanaman Modal Asing (PMA) dan Penanaman Modal Dalam Negeri (PMDN) menjadi salah satu sumber pembiayaan yang penting bagi wilayah yang sedang berkembang dan mampu memberikan kontribusi yang cukup besar bagi pembangunan. Sebagai salah satu komponen aliran modal, PMA dianggap sebagai aliran modal yang relatif stabil dibandingkan dengan aliran modal lainnya, misalnya investasi portofolio maupun utang luar negeri.

Perkembangan PDB, Investasi (PMA dan PMDN), di Indonesia Tahun 2005-2009 dapat dilihat pada tabel 1 sebagai berikut :

\section{Tabel 1}

\section{Perkembangan Produk Domestik Bruto dan Investasi di Indonesia} Tahun 2005 -2009

\begin{tabular}{|c|c|c|c|c|}
\hline \multirow{2}{*}{ Tahun } & \multicolumn{2}{|c|}{ PDB } & \multicolumn{2}{c|}{ Investasi } \\
\cline { 2 - 5 } & $\begin{array}{c}\text { Laju } \\
(\%)\end{array}$ & $\begin{array}{c}\text { Nilai } \\
\text { (miliar } \\
\text { rupiah) }\end{array}$ & $\begin{array}{c}\text { PMDN } \\
\text { (miliar } \\
\text { rupiah) }\end{array}$ & $\begin{array}{c}\text { PMA } \\
\text { (juta } \\
\text { US\$) }\end{array}$ \\
\hline 2005 & 5.68 & $1.750 .656,1$ & 30.665 & $8.916,9$ \\
\hline 2006 & 5.5 & $1.847 .126,7$ & $20.788,4$ & 5.977 \\
\hline 2007 & 6.35 & $1.963 .091,8$ & 34.878 .7 & 10.349 .6 \\
\hline 2008 & 6.01 & $2.082 .456,1$ & $20.363,4$ & $14.871,4$ \\
\hline 2009 & 4.58 & $2.177 .741,7$ & $37.799,9$ & 10.815 .2 \\
\hline
\end{tabular}

\section{Sumber: Data PDB dan Investasi di dapat dari publikasi BPS}

Dengan melihat pada tabel 1, dapat disimpulkan bahwa laju pertumbuhan produk domestik bruto terus meningkat walaupun sempat turun pada 2006 tetapi dapat meningkat lagi pada 2007, walaupun 
kembali menurun pada 2008 dan 2009. Laju investasi mengalami naik-turun, terlihat pada PMDN yang menurun pada 2006 kemudian meningkat pada 2007 tetapi menurun lagi pada 2008, begitu pula dengan PMA yang sempat turun pada 2006 tetapi dapat meningkat lagi di 2007 walaupun menurun kembali pada 2009.

Pada periode 2005/2006 terjadi penurunan pada laju pertumbuhan PDB sebesar $0.13 \%$ dari $5.68 \%$ menjadi $5.5 \%$. Penurunan ini diikuti dengan penurunan pada PMDN dari Rp 30.665 miliar menjadi Rp 20.788,4 miliar, penurunan pada PMA dari $8.916,9$ juta US\$ menjadi 5.977 juta US\$.

Perekonomian suatu negara bergantung pada investasi untuk menyelesaikan beberapa masalah ekonomi, krisis dan tantangan. Hal ini disebabkan oleh fakta bahwa investasi di sektor-sektor ekonomi tertentu dapat dengan cepat mengubah berbagai tantangan ekonomi yang kita hadapi sebagai suatu bangsa. Investasi baik swasta maupun publik datang dengan banyak manfaat seperti penciptaan lapangan kerja, peningkatan pendapatan per kapita, pengurangan tingkat kemiskinan, peningkatan standar hidup, peningkatan PDB, dan lain-lain (Ilegbinosa, et al., 2015).

Tujuan dari penelitian ini adalah untuk menguji pengaruh investasi asing dan investasi dalam negeri terhadap pertumbuhan ekonomi (PDB) di Indonesia.

\section{Kerangka Teoritis dan Hipotesis}

\section{Pertumbuhan Ekonomi}

Pertumbuhan ekonomi dapat didefinisikan sebagai perkembangan kegiatan dalam perekonomian yang menyebabkan barang dan jasa yang diproduksikan dalam masyarakat bertambah. Dari satu periode ke periode lainnya kemampuan suatu negara untuk menghasilkan barang dan jasa akan meningkat. Kemampuan yang meningkat ini disebabkan karena faktor-faktor produksi akan selalu mengalami pertambahan dalam jumlah dan kualitasnya (Sukirno, 2013).

\section{Investasi Asing}

Menurut UU Penanaman Modal No. 25 Tahun 2007 penanaman modal asing adalah kegiatan menanam modal untuk melakukan usaha di wilayah negara Republik Indonesia yang dilakukan oleh penanam modal asing, baik yang menggunakan modal asing sepenuhnya maupun yang berpatungan dengan penanam modal dalam negeri.

\section{Investasi Dalam Negeri}

Menurut UU Penanaman Modal No. 25 Tahun 2007, penanaman modal dalam negeri adalah kegiatan menanam modal untuk melakukan usaha di wilayah negara Republik Indonesia yang dilakukan oleh penanam modal dalam negeri dengan menggunakan modal dalam negeri.

\section{Pengembangan Hipotesis}

\section{Pengaruh Investasi Asing Terhadap Pertumbuhan Ekonomi}

Investasi asing memainkan peran penting dalam pertumbuhan ekonomi negara-negara berkembang. Ini mempengaruhi skenario pekerjaan, produksi, harga, pendapatan, impor, ekspor, kesejahteraan umum negara penerima, dan neraca pembayaran dan berfungsi sebagai salah satu sumber penting pertumbuhan ekonomi (Hussain dan Haque, 2016).

Hasil penelitian Purwanto dan Mangeswari (2011), Lean dan Tan (2011), Trisnu dan Purbadharmaja (2014), Zekarias (2016), Ibrahim dan Dahie (2016), Iamsiraroj (2016), Mahriza dan Amar (2019), Tran dan Hoang (2019) menunjukkan bahwa investasi asing berpengaruh positif signifikan terhadap pertumbuhan ekonomi, sedangkan hasil penelitian Jufrida, dkk (2016) menunjukkan bahwa investasi asing tidak berpengaruh terhadap pertunbuhan ekonomi. 
Berdasarkan uraian di atas maka hipotesis pertama dapat dirumuskan sebagai berikut: $\mathrm{H}_{1}$ :Investasi asing berpengaruh positif terhadap pertumbuhan ekonomi.

\section{Pengaruh Investasi Dalam Negeri Terhadap Pertumbuhan Ekonomi}

Teori pertumbuhan ekonomi yang dikembangkan oleh kaum Neo-Klasik menekankan peranan modal yang dimiliki suatu negara. Modal yang bersumber dari dalam negeri maupun luar negeri akan membantu perekonomian suatu negara. Investasi dalam negeri atau yang juga dikenal dengan nama Penanaman Modal Dalam Negeri (PMDN) dianggap mampu mendorong perekonomian suatu negara berkembang dengan sangat baik, dimana jika investasi yang terjadi di dalam negeri mengalami peningkatan maka akan meningkatkan pertumbuhan ekonomi (Jufrida, 2016).

Hasil penelitian Trisnu dan Purbadharmaja (2014), Jufrida, dkk (2016), Ibrahim dan Dahie (2016), Emmanuel dan Kehinde (2018) Mahrisa dan Amar (2019), Tran dan Hoang (2019) menunjukkan bahwa investasi dalam negeri berpengaruh positif signifikan terhadap pertumbuhan ekonomi, sedangkan hasil penelitian Lean dan Tan (2011) menunjukkan bahwa investasi dalam negeri berpengaruh negatif terhadap pertumbuhan ekonomi.

Berdasarkan uraian di atas maka hipotesis kedua dapat dirumuskan sebagai berikut :

$\mathrm{H}_{2}$ : Investasi dalam negeri berpengaruh positif terhadap pertumbuhan ekonomi.

Mengacu pada hipotesis yang telah dinyatakan, kerangka konseptual dapat dilihat pada Gambar 1 berikut:

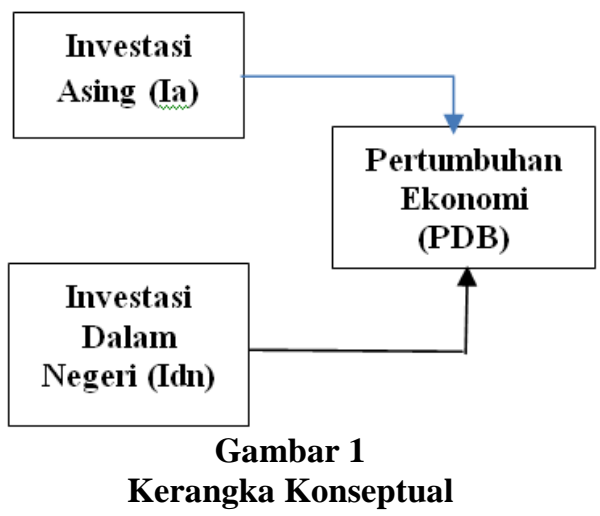

\section{Metode Penelitian}

Metode yang digunakan dalam penelitian ini adalah metode kuantitatif. Metode kuantitatif adalah metode penelitian yang berlandaskan pada filsafat positivisme, digunakan untuk meneliti pada populasi atau sampel tertentu, pengumpulan data menggunakan instrumen penelitian, analisis data bersifat kuantitatif/statistik, dengan tujuan untuk menggambarkan dan menguji hipotesis yang telah ditetapkan (Sugiyono, 2017).

\section{Objek Penelitian}

Objek dalam penelitian investasi asing, investasi dalam negeri dan pertumbuhan ekonomi di Indonesia.

\section{Operasionalisasi Variabel}

Terdapat 2 variabel dalam penelitian ini yaitu variabel independen dan variabel dependen.

1. Variabel independen terdiri dari :

a. Investasi $\operatorname{Asing}\left(\mathbf{I}_{\mathbf{a}}\right)$

Investasi Asing adalah realisasi dari penanaman modal yang dilakukan oleh pemilik-pemilik modal asing secara langsung berdasarkan peraturan penanaman modal asing, ketentuan umum dan prosedur penanaman modal asing oleh pemerintah. 


\section{b. Investasi Dalam Negeri $\left(\mathbf{I}_{\mathrm{dn}}\right)$}

Investasi Dalam Negeri adalah realisasi dari penanaman modal yang dilakukan oleh pemilikpemilik modal dalam negeri secara langsung berdasarkan peraturan penanaman modal dalam negeri, ketentuan umum dan prosedur penanaman modal dalam negeri oleh pemerintah.

2. Variabel dependen yaitu pertumbuhan ekonomi. Pertumbuhan ekonomi diukur menggunakan Produk Domestik Bruto (PDB). Produk Domestik Bruto adalah besarnya nilai realisasi pendapatan di Indonesia yang diukur berdasarkan harga konstan tahun 2000 .

\section{Jenis dan Sumber Data}

Adapun jenis data yang dipakai dalam penelitian ini yaitu data yang diperoleh dari beberapa sumber publikasi, meliputi data tentang; Produk Domestik Bruto (PDB atas berlaku dan konstan), Investasi Dalam Negeri dan Investasi Asing.

\section{Metode Pengumpulan Data}

Dalam penelitian ini data yang digunakan adalah data sekunder, yaitu data cross section per provinsi di Indonesia tahun 2011. Menurut sumbernya, data tersebut terdiri atas:

1. Data PMDN yang diperoleh dari Badan Pusat Statistik.

2. Data PMA yang diperoleh dari Badan Pusat Statistik.

3. Data PDB atas dasar harga konstan yang diperoleh dari Badan Pusat Statistik

\section{Metode Analisis}

Metode analisis data yang digunakan adalah metode regresi berganda. Persamaan regresi untuk menguji hipotesis 1 dan 2 adalah :

$$
\mathrm{PDB}=\alpha+\beta_{1} \mathrm{Ia}+\beta_{2} \operatorname{Idn}+\varepsilon
$$

Keterangan :

PDB $=$ Pertumbuhan ekonomi

Ia $=$ Investasi asing

Idn = Investasi dalam negeri

$\alpha \quad=$ Konstanta

$\beta_{1}, \beta_{2}=$ Koefisien Regresi

$\varepsilon \quad=$ Error

\section{Hasil Penelitian dan Pembahasan}

\section{Pengujian Asumsi Klasik}

\section{Uji Normalitas}

Uji normalitas bertujuan untuk menguji apakah dalam model regresi, variabel bebas dan variabel terikat keduanya terdistribusi secara normal ataukah tidak. Untuk melihat suatu data terdistribusi secara normal adalah dengan cara menggunakan uji statistik Kolmogorov Smirnov (K-S). Data dikatakan normal jika angka signifikan (Asimp Sig) lebih besar dari 0,05 atau 5\%. Dan hasilnya diketahui melalui hasil uji SPSS 16.0.

Uji normalitas dapat dilihat pada Tabel 2 sebagai berikut :

\section{Tabel 2}

Uji Normalitas

One-Sample Kolmogorov-Smirnov Test

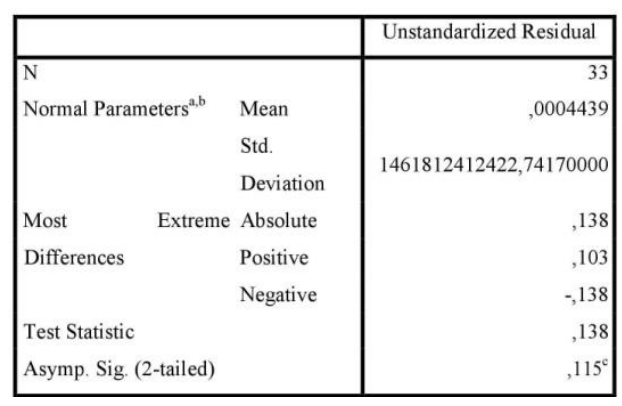

Dari tabel 2 dapat dilihat bahwa nilai asymp sig (2-tailed) adalah 0,115, lebih besar dari 0,05 artinya datanya berdistribusi normal.

\section{Uji Multikolinearitas}

Uji Multikolinearitas bertujuan menguji apakah ditemukan adanya korelasi antara 
variabel independen pada model regresi. Pada model regresi yang baik seharusnya tidak terjadi korelasi diantara varibel independen. Untuk mengetahui ada atau tidaknya multikolinearitas maka dapat dilihat dari nilai Varians Inflation Factor (VIF ) dan nilai Tolerance. Bila nilai VIF lebih kecil dari 10 dan nilai Tolerance lebih besar dari 0,1 artinya tidak terjadi multikolinearitas.

Uji multikolinearitas dapat dilihat pada table 3 sebagai berikut :

Tabel 3

Uji Multikolinearitas Coefficients $^{\mathrm{a}}$

\begin{tabular}{|c|c|c|c|c|c|c|c|}
\hline \multirow[b]{2}{*}{ Model } & \multicolumn{2}{|c|}{ Unstandardized Coefficients } & \multirow{2}{*}{$\begin{array}{c}\text { Standardized } \\
\text { Coefficients } \\
\text { Beta }\end{array}$} & \multirow[b]{2}{*}{1} & \multirow[b]{2}{*}{ Sig. } & \multicolumn{2}{|c|}{ Collineanty Statistics } \\
\hline & B & Stid. Error & & & & Tolerance & VIF \\
\hline $1 \quad$ (Constant) & & 40279268980 & & & & & \\
\hline IA & ,027 & 004 & 873 & 6,360 & , 000 &, 250 & 3,998 \\
\hline $\mathbb{D N N}$ & 3,901 & 8,718 & ,061 & , 448 & .658 & ,250 & 3,998 \\
\hline
\end{tabular}

Dari tabel 3 diketahui bahwa VIF lebih kecil dari 10 dan nilai Tolerance di atas 0,1 . Hal ini menunjukkan bahwa dalam model ini, tidak terjadi multikolinearitas.

\section{Uji Heteroskedastisitas}

Uji heteroskedastisitas bertujuan untuk mengetahui apakah pada model ini terjadi ketidaksamaan varian dari residual satu pengamatan ke pengamatan yang lain tetap, maka disebut homoskedastisitas dan jika berbeda disebut heteroskedastisitas. Model yang baik adalah model yang tidak terjadi heteroskedastisitas.

Dalam pengujian ini heteroskedastisitas menggunakan metode Rank Sperman dengan kriteria dikatakan terbebas heteroskedastisitas apabila nilai signifikasi atau sig (2- tailed) lebih besar dari alpha 0,05 atau5\%.
Uji heteroskedastisitas dapat diilihat dari tabel 4 sebagai berikut:

Tabel 4

Uji Heteroskedastisitas

Coefficients $^{\mathrm{a}}$

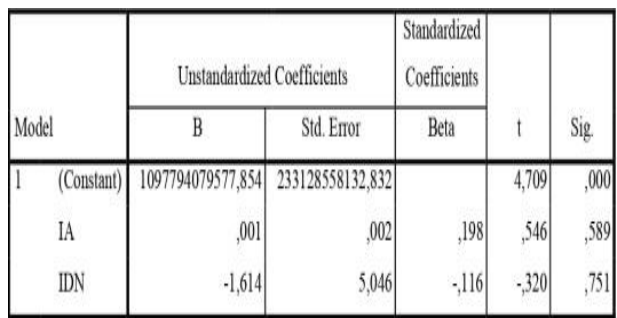

Dari tabel 4 diketahui nilai signifikansi lebih besar dari 0,05 yang menunjukkan bahwa penelitian ini terbebas dari masalah heteroskedastisitas.

\section{Analisis Regresi Linier Berganda}

Metode analisis data yang digunakan dalam penelitian ini adalah metode Regresi Linier Berganda. Analisis Regresi Linier Berganda adalah analisis yang digunakan untuk mengetahui ada tidaknya pengaruh variabel independen terhadap variabel dependen. Tabel 5 disajikan sebagai berikut :

\section{Tabel 5}

Cotficients'

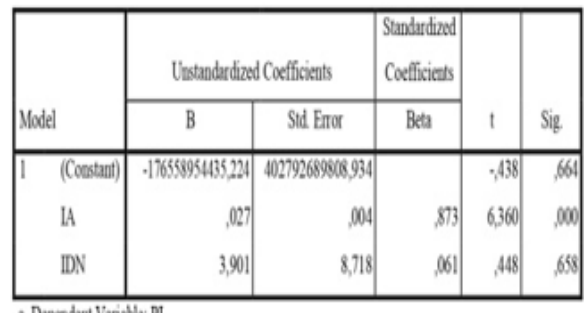

a Dependent Vanadk. PI

Dari tabel 5, persamaan regresi adalah sebagai berikut :

$$
\mathrm{PDB}=-176558954435,224+0,27 \mathrm{Ia}+
$$
$3,901 \mathrm{Idn}$ 


\section{Pengujian Hipotesis}

Dalam penelitian ini, peneliti melakukan uji hipotesis dengan taraf kepercayaan 95\%, dengan syarat sebagai berikut:

1. Hipotesis ditolak, jika nilai signifikansi lebih besar atau sama dengan $\alpha=0.05$, yang berarti tidak terdapat pengaruh variabel independen terhadap variabel dependen variabel.

2. Hipotesis diterima,jika nilai signifikansi lebih kecil dari $\alpha=0.05$, yang berarti terdapat pengaruh antara variabel independen terhadap variabel dependen.

\section{Hasil Pengujian Hipotesis 1}

Berdasarkan table 5, variabel investasi asing memiliki nilai signifikansi lebih kecil dari 0,05 yang berarti tolak $\mathrm{H}_{0}$ yang berarti bahwa investasi asing berpengaruh positif signifikan terhadap pertumbuhan ekonomi. Hasil penelitian ini mendukung penelitian Purwanto dan Mangeswari (2011), Lean dan Tan (2011), Trisnu dan Purbadharmaja (2014), Zekarias (2016), Ibrahim dan Dahie (2016), Iamsiraroj (2016), Mahriza dan Amar (2019), Tran dan Hoang (2019) yang menunjukkan bahwa investasi asing berpengaruh positif signifikan terhadap pertumbuhan ekonomi. Hasil penelitian ini tidak mendukung penelitian Jufrida, dkk (2016) yang menunjukkan bahwa investasi asing tidak berpengaruh terhadap pertunbuhan ekonomi.

Hasil dari penelitian ini
menunjukkan bahwa
tujuan dari penyelenggaraan investasi Penanaman Modal Asing (PMA) di Indonesia untuk meningkatkan pertumbuhan ekonomi dapat dicapai.

\section{Hasil Pengujian Hipotesis 2}

Berdasarkan table 5, variabel investasi dalam negeri memiliki nilai signifikansi 0,658 , lebih besar dari 0,05 yang berarti terima $\mathrm{H}_{0}$ yang berarti bahwa investasi dalam negeri tidak berpengaruh terhadap pertumbuhan ekonomi. Hasil penelitian ini tidak mendukung penelitian Trisnu dan Purbadharmaja (2014), Jufrida, dkk (2016),
Ibrahim dan Dahie (2016), Emmanuel dan Kehinde (2018) Mahrisa dan Amar (2019), Tran dan Hoang (2019) yang menunjukkan bahwa investasi dalam negeri berpengaruh positif signifikan terhadap pertumbuhan ekonomi. Hasil penelitian ini tidak mendukung penelitian Lean dan Tan (2011) yang menunjukkan bahwa investasi dalam negeri berpengaruh negatif terhadap pertumbuhan ekonomi.

Apabila melihat dari persamaan regresi menunjukkan bahwa koefisien dari variabel investasi dalam negeri adalah positif berarti investasi dalam negeri pada dasarnya akan meningkatkan pertumbuhan ekonomi, tetapi dalam penelitian ini investasi dalam negeri tidak berpengaruh signifikan terhadap pertumbuhan ekonomi. Untuk itu investasi dalam negeri perlu untuk ditingkatkan sehingga akan meningkatkan pertumbuhan ekonomi Indonesia.

\section{Simpulan dan Saran}

\section{Simpulan}

Simpulan dari penelitian ini adalah:

1. Investasi asing berpengaruh positif signifikan terhadap pertumbuhan ekonomi.

2. Investasi dalam negeri tidak berpengaruh terhadap pertumbuhan ekonomi

\section{Saran}

Berdasarkan hasil dalam penelitian ini, peneliti mengemukakan saran sebagai berikut:

\section{Bagi Pemerintah}

1. Pemerintah harus memberikan perhatian yang penuh terhadap investasi dalam negeri, karena peningkatan investasi di dalam negeri memberi dampak yang sangat luas dan positif terhadap perekonomian Indonesia, lewat multiplier effect di segala sektor 
ekonomi.

2. Ketika ekonomi global kurang positif tumbuhnya, sehingga mengurangi arus masuk modal dari luar negeri, maka pemerintah sebaiknya membuat regulasi atau kemudahan untuk pengusaha dalam negeri sehingga mau untuk berinvestasi di dalam negeri, guna meningkatkan perekonomian Indonesia.

3. Peningkatan perekonomian Indonesia sangat dipengaruhi oleh investasi asing dan investasi dalam negeri, selain itu nilai peningkatan ekspor dan arus kunjungan wisata kedalam negeri yang berdampak terhadap peningkatan penerimaan devisa bagi perekonomian Indonesia.

\section{Bagi Peneliti Selanjutnya}

1. Bagi peneliti selanjutnya yang akan meneliti pengaruh investasi terhadap pertumbuhan ekonomi disarankan untuk meneliti dalam periode penelitian yang panjang karena pertumbuhan ekonomi merupakan masalah makro ekonomi dalam jangka panjang.

2. Peneliti selanjutnya dapat menambahkan variabel-variabel lain di luar dari penelitian ini, yang mungkin dapat mempengaruhi pertumbuhan ekonomi seperti: tenaga kerja, tabungan, infrastruktur, dan teknologi, sehingga dapat diperoleh hasil penelitian yang lebih baik.

\section{Daftar Pustaka}

Emmanuel, O.G., \& Kehinde, A. (2018) "Domestic Investment and Economy Growth in Nigeria : An Empirical Investigation", International Journal of Business and Social Science,Vol. 9, Number 2, ISSN 2219-6021, www.ijbssnet.com.

Hussain, M.E.,\& Haque, M. (2016) "Foreign Direct Investment, Trade, and Economic Growth : An Empirical Analysis of Bangladesh", Economies,
4,7, doi : 10. 3390/economies 4020007. Iamsiraroj, S. (2016) "The Foreign Direct Investment-Economic Growth Nexus", International Review of Economics and Finance 42, pp 116-133, http://dx.doi.org/10.1016/j.iref.2015.10. 044.

Ibrahim, A.A., \& Dahie, A.M. (2016). "The Effect of Foreign Direct Investment, Foreign Aid and Domestic Investment on Economic Growth: Evidence from Somalia", Imperial Journal of Interdisciplinary Research (IJIR), Vol-2, Issue-13, ISSN: 2454-1362, http://www.onlinejournal.in. Ilegbinosa, I.A., Micheal, A., \& Watson, S.I. (2015). "Domestic Investment and Economic Growth in Nigeria From 1970-2013 : An Econometric Analysis", Canadian Social Science, Vol. 11, No. 6, pp 70-79, DOI : 103968/7009.

Jufrida, F., Syechalad, M.N., \& Nasir, M. (2016) "Analisis Pengaruh Investasi Langsung (FDI) dan Investasi Dalam Negeri Terhadap Pertumbuhan Ekonomi Indonesia", Jurnal Perspektif Ekonomi Darussalam,Volume 2, Nomor 1, ISSN 2502-6976.

Lean, H.H., \& Tan, B.W. (2011). "Linkages between Foreign Direct Investment and Economic Growth in Malaysia", Journal of Economic Cooperation and Development 32, 4, pp 75-96.

Mahriza, T., \& Amar, S.B. (2019). "Pengaruh Investasi Dalam Negeri, Investasi Asing, Tenaga Kerja dan Infrastruktur Terhadap Perekonomian di Provinsi Sumatera Barat", Jurnal Kajian Ekonomi dan Pembangunan, volume 1, Nomor 3, Hal 691-704.

Murni, A. (2016). "Ekonomi Makro", Edisi Revisi, PT Refika Aditama, Bandung.

Purwanto, N.P., \& Mangeswari, D.R. (2011) "Pengaruh Investasi Asing dan Hutang Luar Negeri Terhadap Pertumbuhan Ekonomi Indonesia", Jurnal Ekonomi \& Kebijakan Publik, Vol.2, No.2, 681-705.

Sugiyono. (2017). “Metode Penelitian 
Bisnis Pendekatan Kuantitatif, Kualitatif, Kombinasi, dan R\&D”, Edisi Ketiga, CV Alfabeta, Bandung.

Sukirno, S. (2013). "Makro ekonomi Teori Pengantar", Edisi Ketiga, PT Raja Grafindo Persada, Jakarta.

Tran, H.T.T.,\& Hoang, H.T. (2019) “An Investigation into the Impacts of FDI, Domestic Investment Capital, Human Resourcesm and Trained Workers on Economic Growth in Vietnam", International Econometric Conference of Vietnam-Springer.

Trisnu, C.I.S.R., \& Purbadharmaja, I.B.P. (2014) "Pengaruh PMDN dan PMA Terhadap PDRB di Provinsi Bali",EJurnal Ekonomi Pembangunan Universitas Udayana, Volume 3, Nomor 3, hal 88-95, ISSN 2303-0178.

Undang-Undang Republik Indonesia Nomor 25 Tahun 2007 Tentang Penanaman Modal.

Zekarias, S.M. (2016) "The Impact of Foreign Direct Investment (FDI) on Economic Growth in Eastern Africa : Evidence from Panel Data Analysis", Applied Economcs and Finance, Vol. 3, No. 1,ISSN 2332-7294, URL http://dx.doi.org/10.11114/aef.v3il.1317 